\title{
Isoprenoid Alcohol Kinase - a Third Butanol-soluble Enzyme in Klebsiella aerogenes Membranes
}

\author{
By I. R. POXTON, J. A. LOMAX AND I. W. SUTHERLAND \\ Department of Microbiology, University of Edinburgh, \\ Edinburgh $\mathrm{EH}_{9}{ }_{3} \mathrm{JG}$
}

(Received I 8 April 1974)

Isoprenoid alcohols function in bacteria as the acceptors on which polysaccharide molecules are assembled. In this role they are involved in the biosynthesis of mucopeptide (Anderson, Matsuhashi, Haskin \& Strominger, I965), lipopolysaccharide (Wright, Dankert \& Robbins, 1965), teichoic acids (Anderson, Hussey \& Baddiley, 1972) and extracellular capsular or slime polysaccharides (Sutherland \& Norval, I970; Troy, Frerman \& Heath, I97I). In growing Klebsiella aerogenes three of these polymers are formed, but only the extracellular polysaccharide continues to be synthesized after the bacteria have reached the stationary phase of growth. This indicates that there must be some kind of control to ensure that the isoprenoid alcohol of the organism is available for manufacture of the essential wall polymers during growth but can also function in capsule formation during and after active growth. There is some indication that conditional mutants presumed to be defective in isoprenoid lipid content synthesize only the wall polymers until growth has ceased, when capsular polysaccharide synthesis commences (Sutherland, 1972).

A possible control mechanism for isoprenoid alcohol in Staphylococcus aureus was suggested by Strominger and his colleagues following the discovery of an isoprenoid alcohol kinase and a $\mathrm{C}_{55}$-isoprenoid alcohol phosphatase in that species (Sandermann \& Strominger, 1972; Willoughby, Higashi \& Strominger, 1972). The two enzymes were thought to control the carrier lipid - the kinase making it available, and the phosphatase removing it from the systems requiring it. The isoprenoid alcohol enters the biosynthetic cycle for mucopeptide or for lipopolysaccharide as the phosphate. Subsequently, it accepts a monosaccharide-Iphosphate moiety from a nucleoside diphosphate sugar. After addition of various other monosaccharides or similar compounds, transfer of the oligosaccharide formed to an appropriate acceptor molecule leaves isoprenoid lipid as a pyrophosphate. It is unable to re-enter the biosynthetic cycle for the polymers until it has been dephosphorylated by the specific phosphatase. A second enzyme accomplished further dephosphorylation to yield the free isoprenoid alcohol. The kinase described by Sandermann \& Strominger (1972) rephosphorylated free isoprenoid alcohol to the active monophosphate form. If this control operates, such systems will be widely distributed among bacteria and may have an even more important role in those species which possess extracellular polysaccharides in addition to wall polysaccharides.

In general, membranes can be prepared more readily from Gram-positive than from Gram-negative bacteria to permit extraction of the membrane-bound enzymes by the acidbutanol technique of Sandermann \& Strominger (1972). Extraction of whole Klebsiella aerogenes with acid butanol yielded little protein and none with detectable enzymic activities. When the $K$. aerogenes were broken in an Aminco pressure cell the membranes (contaminated with wall material) could be separated from unbroken bacteria. Acid butanol extraction then 


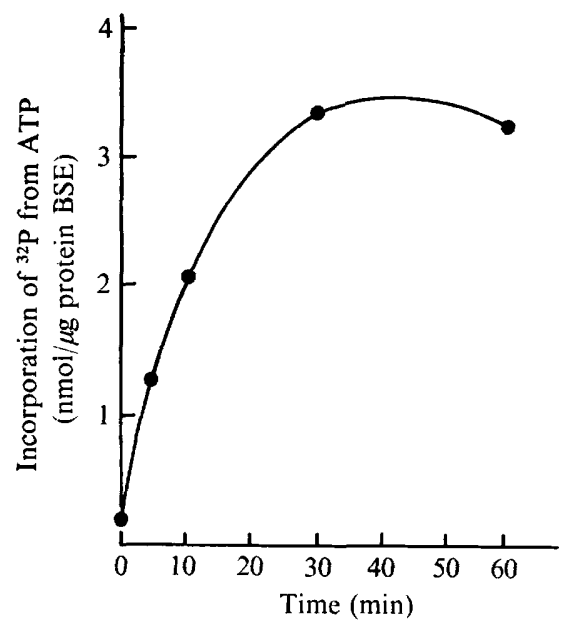

Fig. I. $\mathrm{C}_{55}$ alcohol phosphokinase activity in crude butanol-soluble enzyme (BSE). The activity of crude butanol-soluble extracts was tested by removing $50 \mu \mathrm{l}$ samples from the incubation mixture and applying them directly to paper, as described by Sandermann \& Strominger (1972). After development of the chromatograms for 4 to $5 \mathrm{~h}$, the front area was cut out and its radioactivity estimated directly in a toluene-based scintillation fluid.

dissolved up to $5 \%$ of the membrane protein. Two enzymic activities, a glucosyl-phosphate transferase and a galactose transferase, both essential for synthesis of the capsular polysaccharide of $K$. aerogenes type 8, were detected (Lomax, Poxton \& Sutherland, 1973). In whole bacteria, the glucose-I-phosphate transferase requires the presence of $C_{55}$ isoprenoid alcohol phosphate as acceptor in the reaction:

Isoprenoid alcohol phosphate + UDP-glucose $\rightarrow$ Isoprenoid alcohol-P-P-glucose + UMP.

Two non-mucoid mutan ts of $K$. aerogenes type 8 were used as sources of membrane material, because membranes from capsulate bacteria were recovered with lower yields. After breakage of the bacteria, membranes were recovered by differential centrifugation and extracted three times with acid butanol [butanol-6 M-pyridinium acetate $(8: 3), \mathrm{pH}_{4} \cdot 2$, at room temperature]. Partial purification was achieved by precipitation from solvent solution at $0{ }^{\circ} \mathrm{C}$ (inactive material) and then at $-20^{\circ} \mathrm{C}$ (active protein). The brownish precipitate from each preparation was redissolved in butan- $\mathrm{I}-\mathrm{ol}$ and held at $0^{\circ} \mathrm{C}$. This was used as 'enzyme'. It lacked endogenous acceptor and this was normally replaced with added ficaprenyl phosphate prepared by chemical phosphorylation of ficaprenol (Stone, Wellburn, Hemming \& Pennock, 1967). Alternatively, ficaprenol or the $\mathrm{C}_{55}$-isoprenoid alcohol from bacteria (bactoprenol) and ATP could replace the alcohol phosphate, suggesting that the 'enzyme' contained a kinase with similar specificity to that described by Sandermann \& Strominger (1972). When 'enzyme' and bactoprenol, which had been dried together under vacuum, were suspended in a buffer containing: $50 \mathrm{mM}-\mathrm{tris}-\mathrm{HCl} \mathrm{pH} 8.5,10 \mathrm{mM}-\mathrm{Mg}^{++}$, $100 \mathrm{mM}-\mathrm{P}_{\mathrm{i}}$, $600 \mathrm{~mm}$-dimethyl sulphoxide, $0.1 \% 2$-mercaptoethanol and $0.3 \%$ Triton X-100, addition of $0.05 \mu \mathrm{Ci}(0.1 \mu \mathrm{mol})$ of ATP- $\gamma^{32}-\mathrm{P}$ yielded a radioactive product soluble in chloroform. This product moved at the solvent front on paper chromatography in isobutyric acid + I Mammonia (5:3). Results from the two mutant strains were identical. Assay of lipid phosphate formation by this technique (Sandermann \& Strominger, 1972) showed that the reaction increased with time over a period of about $30 \mathrm{~min}$. Thereafter, a slight but reproducible decrease in product occurred (Fig. I). This may have been due to the presence of a specific phosphatase in the reaction mixture. Similar results were obtained when ficaprenol was used 
as acceptor instead of the bacterial $\mathrm{C}_{55}$ isoprenoid alcohol. Controls without added acceptor did not transfer phosphate to lipid-soluble material. Paper chromatograms of complete incubation mixtures scanned in a $4 \pi$ scanner showed three peaks, two of which were unreacted ATP and inorganic phosphate, while the third, at the solvent front, was assumed to be isoprenoid alcohol phosphate.

To test the identity of the product of enzyme action, incubation mixtures were extracted with chloroform + methanol $(2: \mathrm{I}, \mathrm{v} / \mathrm{v})$. The chloroform solutions were thoroughly washed with $0.9 \%(\mathrm{w} / \mathrm{v}) \mathrm{NaCl}$ and separated from the aqueous phase by passage through Whatman IPS papers. Thin-layer chromatography of the chloroform solution in diisobutyl-ketone + acetic acid + water (40:25:5, by vol.) revealed a single radioactive product with $R_{F} 0 \cdot 6$. This is similar to the mobility in this solvent of chemically prepared ficaprenyl or bactoprenyl phosphate run on the same chromatograms and stained with a solution of $5 \%(\mathrm{w} / \mathrm{v})$ $p$-anisaldehyde in a solution of concentrated $\mathrm{H}_{2} \mathrm{SO}_{4}+90 \%$ ethanol (I:I8). Some other isoprenoid alcohols of various chain lengths may also act as substrates, although less effectively than ficaprenol or bactoprenol.

The presence of an isoprenoid alcohol kinase, the third butanol-soluble enzyme isolated from $K$. aerogenes membranes, supports the suggestion of Sandermann \& Strominger (I972) that enzymic phosphorylation and dephosphorylation of $\mathrm{C}_{55}$ isoprenoid alcohols provides a regulation mechanism for the synthesis of polysaccharides by bacterial membranes. If this is the role of the kinase, it should prove to be an enzyme of widespread occurrence. As yet, it has been found only in one Gram-positive and one Gram-negative bacterial species, but preliminary results (K. Jann, H. Kopmann and .I. W. Sutherland, unpublished results) suggest that it can also be isolated from Escherichia coli by the techniques described here. It is probable that although a common means of enzyme extraction can be used for membranes from Gram-positive and Gram-negative bacteria, there are sufficient differences in the enzymes from different bacteria to require distinct purification procedures.

\section{REFERENCES}

Anderson, J. S., Matsuhashi, M., Haskin, M. \& Strominger, J. L. (1965). Lipid-phosphoacetylmuramylpentapeptide and lipid-phosphodisaccharide-pentapeptide: presumed membrane transport intermediates in cell wall synthesis. Proceedings of the National Academy of Sciences of the United States of America 53, $88 \mathrm{I}-889$.

Anderson, R. G., Hussey, H. \& Baddiley, J. (1972). The mechanism of wall synthesis in bacteria. The organisation of enzymes and isoprenoid phosphates in membrane. Biochemical Journal 127, I I-25.

Lomax, J. A., Poxton, I. R. \& Sutherland, I. W. (I973). Butanol-soluble glycosyl transferases in Klebsiella aerogenes. FEBS Letters 34, 232-234.

Sandermann, H. \& Strominger, J. L. (1972). Purification and properties of $\mathrm{C}_{55}$-isoprenoid alcohol phosphokinase from Staphylococcus aureus. Journal of Biological Chemistry 247, 5123-5I I.

Stone, K. J., Wellburn, A. R., Hemming, F. W. \& Pennock, J. F. (1967). The characterization of ficaprenolIO, -I I and -I 2 from the leaves of Ficus elastica (decorative rubber plant). Biochemical Journal ro2, 325-330.

Sutherland, I. W. \& Norval, M. (1970). The synthesis of exopolysaccharide by Klebsiella aerogenes membrane preparations and the involvement of lipid intermediates. Biochemical Journal 120, 567-576.

Sutherland, I. W. (1972). Bacterial exopolysaccharides. Advances in Microbial Physiology 8, I43-21 3.

Troy, F. A., Frerman, F. E. \& Heath, E. C. (I971). The biosynthesis of capsular polysaccharide in Aerobacter aerogenes. Journal of Biological Chemistry 246, I I8-I 33.

Willoughby, E., Higashi, Y. \& Strominger, J. L. (1972). Enzymatic dephosphorylation of $\mathrm{C}_{55}$-isoprenoid alcohol pyrophosphate. Journal of Biological Chemistry 247, 5I I6-5I 22.

Wright, A., DANKert, M. \& Robbins, P. W. (1965). Evidence for an intermediate stage in the biosynthesis of the salmonella $O$-antigen. Proceedings of the National Academy of Sciences of the United States of America 54, 235-24I. 